\title{
Corrigenda
}

\section{Postmortem Brain: An Underutilized Substrate for Studying Severe Mental Illness}

Robert E McCullumsmith, John H Hammond, Dan Shan and James H Meador-Woodruff

Neuropsychopharmacology (20 I5) 40, I307; doi:I0.1038/npp.2014.337

Correction to: Neuropsychopharmacology Reviews (2014) 39, 65-87; doi:10.1038/npp.2013.239; published online 30 October 2013
In this article, the reference Miner et al. was incorrectly cited in Table 1.

\section{Ketamine: Promising Path or False Prophecy in the Development of Novel Therapeutics for Mood Disorders?}

\author{
Gerard Sanacora and Alan F Schatzberg
}

Neuropsychopharmacology (2015) 40, 1307; doi:1 0.1038/npp.2014.338

Correction to: Neuropsychopharmacology (2015) 40, 259-267; doi:10.1038/npp.2014.261; published online 22 October 2014

On page 262 (first paragraph under 'Ketamine's Abuse Liability: Mu Opioid Receptor Effects'), the references to lambda opioid receptors and lambda antagonists should have been to delta opioid receptors and delta antagonists. The same error appears on page 264 (second paragraph under 'Novel Drug Development'). 